\title{
THE MODEL OF THE SUCCESS OF SETTLEMENT TWINNING IN THE HUNGARIAN-CROATIAN CROSS-BORDER REGION
}

\section{A TESTVÉRTELEPÜLÉSI KAPCSOLATOK SIKERESSÉGÉNEK MODELLJE A MAGYAR-HORVÁT HATÁRTÉRSÉGBEN}

\author{
Krisztina KELLER ${ }^{\mathrm{a}}$, Kristina SVRŽNJAK ${ }^{\mathrm{b}}$, Nikoletta KASZÁS ${ }^{\mathrm{a}}$ \\ a Szent University of Pannonia Nagykanizsa Campus, Address: 18. Zrínyi utca, Nagykanizsa, 8800, \\ Hungary, phone: + 3693 502 914; + 3693 502913, e-mail: keller.krisztina@uni-pen.hu; \\ kaszas.nikoletta@uni-pen.hu \\ ${ }^{\mathrm{b}}$ Križevci College of Agriculture, Address: Milislava Demerca 1., Križevci, 48260, Croatia, phone: +385 \\ 98700 444, e-mail: ksvrznjak@vguk.hr
}

Cite this article: Keller, K., Svržnjak, K., Kaszás, N. (2015). The Model of the Success of Settlement Twinning in the Hungarian-Croatian Cross-Border Region. Deturope, 7, 2: 118-137

\begin{abstract}
The number of twin settlement relations grows continuously in the European countries, including Hungary and Croatia as well. During our quantitative research we examined the inhibitory factors of twin settlement co-operations, the nature of relationships, taking into account the current content of relationships as well. We have also mapped, what benefits the questioned local authorities can expect from the co-operation, which target groups are involved in this, and how intensively they can involve the public. The survey explored the formed municipal and county government cooperations in Zala, Somogy and Baranya counties on the Hungarian side, while on the Croatian side in Međimurska, Koprivničko križevačka, Virovitičko-podravska and Osječko-baranjskacounties. The unique nature and the importance of our work is given by the fact that we provide an answer to the question that how can the success of twin settlement relations be measured.
\end{abstract}

Keywords: twin settlement, Hungary, Croatia, cross-border region, success

\section{Kivonat}

A testvértelepülési kapcsolatok száma folyamatosan nő az európai országokban, így Magyarországon és Horvátországban is. A kvantitatív módszert tartalmazó kutatásunk során górcső alá vettük a testvértelepülési együttműködéseket generáló tényezőket, a kapcsolatok jellegét, jelenlegi tartalmát is górcső alá véve. Feltérképeztük továbbá, hogy a megkérdezett önkormányzatok milyen előnyeit látják az együttmüködésnek, mely célcsoportok vesznek részt ebben, illetve milyen mértékben tudják a lakosságot bevonni. A kérdőíves kutatásunk a magyar oldalon a Zala, Somogy és Baranya megyékben, horvát oldalon pedig Muraköz, Kapronca-Körös, Verőce-Drávamente és Eszék-Baranya megyékben kialakult települési és megyei önkormányzati együttmüködésekre terjedt ki. A munkánk unikális jellegét és jelentőségét az adja, hogy választ kívánunk adni arra a kérdésre, hogyan mérhető a testvérvárosi kapcsolatok sikeressége.

Kulcsszavak: testvértelepülés, Magyarország, Horvátország, határon átrnyúló régió, siker 


\section{INTRODUCTION}

The regions along the borders of East-Central Europe had experienced the negative effects of being borderlands for a long time since such economic, social and ethnic conflicts - partly aroused by the national governments - were present in these areas that led to the decline of these regions and to the break-off from the central territories.

Thanks to the regional politics of the European Union (EU) more attention was paid to the border regions forced into the peripheries; the tenders facilitated the more intensive nature of regional co-operations. All these were reflected in scientific researches as well: the scientific investigation of the separating and connecting roles of frontiers and the issue of cross-border programmes got more and more frequent in social sciences.

The increase of cross-border co-operation is not only important to certain affected states but it is also a common European integration interest since border regions strengthen the economic and social cohesion due to their economic-social compensating roles. Following the EU accession of Hungary and Croatia the cross-border regions got into a more beneficial situation since they received substantial development aid.

The increase of the significance of cross-border co-operations directed our attention to „settlement-twinning networks" since it is one of the main means to build networks on a local level.

\section{OBJECTIVES AND METHODS}

During our quantitative research we have looked at the factors that generated twin-settlement arrangements in the Hungarian-Croatian border region. We also looked at the nature of the relationships and their current content. We have examined, what the interviewed municipalities consider to be the advantages of such cooperation, what target groups are participating in the process and to what extent they can involve the public.

Our work is unique and significant in that regard that we would like to provide an answer to the question of measuring the successfulness of twin settlement relationships.

Based on the database we prepared, 70 Hungarian and 68 Croatian communities have twin settlements in the reviewed region (on the Hungarian side Zala, Somogy and Baranya counties, on the Croatian side Međimurska, Koprivničko-križevačka, Virovitičko-podravska and Osječko-baranjska counties), so these formed the entire population and all of the elements were asked. 
We looked for a person in each settlement between April 1 and May 31 of 2014, who could provide a substantial answer about settlement twinning relationships. The questionnaire was sent out electronically.

58 Hungarian settlements filled out our questionnaire and this number was reduced to 52 after the processing and clarification of the data (51 municipalities and 1 county authority). In case of the Croatian settlements, the number of respondents decreased from 13 to 10 after data processing. The reason for this in case of both countries was that some of the municipalities gave the answer that contrary to the information in the database they do not have Croatian twin settlements. This means that the response rate was $74.43 \%$ in Hungary and $14.7 \%$ in Croatia.

At the beginning of our work we had set up the following model:

Figure 1 Research model

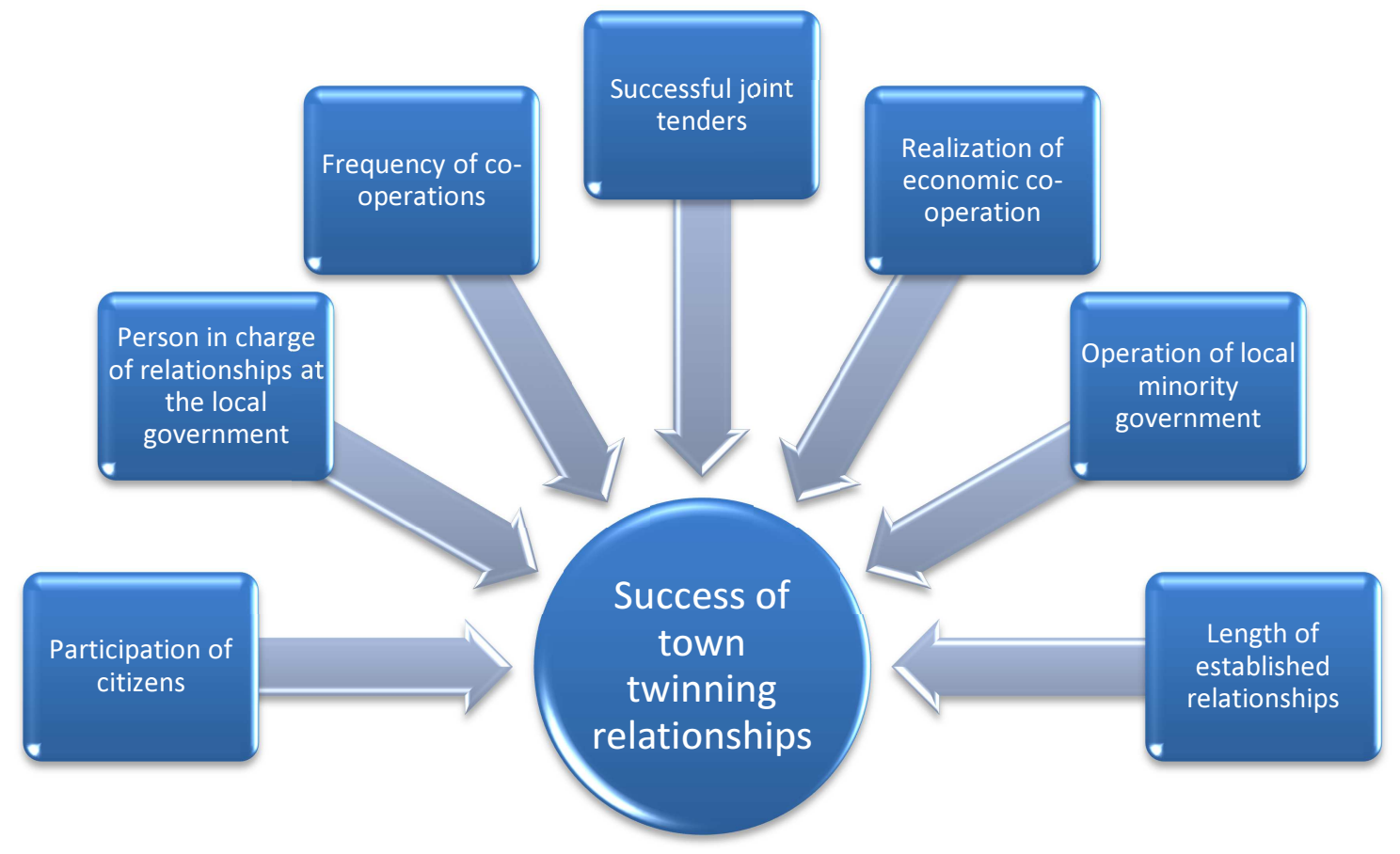

Source: own design of the authors

\section{RESULTS}

\section{History and contents of twin settlement relationships}

Several names for settlement twinning arose in different expressions (twin cities, friendship towns, partner towns, sister cities, brother cities); however, the essence of the cooperation remains the same everywhere. As Jean Bareth, one of the founders of the Council of 
European Municipalities and Regions defined after World War II: „A twinning is the meeting between two municipalities to act together within a European perspective, confronting problems and developing increasingly closer and friendlier ties between one another". ${ }^{17}$

Presently the highest number of twin settlements can be found in the territory of the European Union; the idea of twinning itself was conceived in Western Europe. Following World War I the mutual war tragedies and memories unified nations and meant the beginning of establishing contacts.

Following World War II these relationships gained bigger significance since the primary aim was now to establish peace and to re-build the continent. The first French-German settlement twinning contract between the towns of Montbéliard and Ludwigsburg was set up in this spirit on May 31 1950, which was followed by a number of similar agreements. The fundamental goal of each of these relationships was to bring the different nations and their citizens closer to each other; thus, developing the "Europe of citizens". ${ }^{18}$

On April 281957 the United Towns Organization was established in France with the aim of rendering help in developing co-operations and relationships to those communities that suffered a lot during the war. ${ }^{19}$

A new organization came to life by merging United Towns Organization and International Union of Local Authorities, the aim of the United Cities and Local Governments (UCLG) is to represent and protect the interest of its members in over 100 countries, regardless of the size of the settlements. ${ }^{20}$

UCLG operates as an umbrella organization representing the organizations of seven regions. The Council of European Municipalities and Regions (CEMR) represents European municipalities. $^{21}$

There is no need for an official oath, charter, agreement or signing a brotherly or cooperation contract legally in order to authenticate a twin settlement relationship; however, a formal document encourages the development of a long-term confidential relationship. In

\footnotetext{
17 Mit takar a testvérkapcsolat kifejezés? - Rövid áttekintés áttekintés [What does the term 'twin town connection' refer to? - Summary review] http://www.twinning.org/hu/page/r\%C3\%B6vid$\%$ C3\%A1ttekint\%C3\%A9s\#.U9Forfl_swQ

${ }^{18}$ Bali I., Ürmössy I. (2004). Testvértelepülési kapcsolatok a gyakorlatban [Town twinning connections in practice] Krónika-4 Bt., Szolnok. p. 5.

19 Április 28. A Testvérvárosok Világnapja [28 April - World Twin Town Day] (2013). http:/www.mtva.hu/hu/sajto-es-fotoarchivum/4719-aprilis-28-a-testvervarosok-vilagnapja

${ }^{20}$ The constitution of the world organisation of United Cities and Local Governments. http://www.citieslocalgovernments.org/uclg/upload/template/templatedocs/Constitution.pdf

${ }^{21}$ Introducing CEMR, http://www.ccre.org/en/article/introducing_cemr
} 
default of regulation the form and contents of the settlement twinning agreement or oath are unbound. $^{22}$

The number of settlement twinning relationships was estimated to be over 40,000 in 2009 . Hungary has a distinguished place among European states with its 1,704 settlement twinning relationships; moreover, in proportion to the number of inhabitants it can definitely be considered a leader.

The relatively low number of contacts (279) in the case of Croatia may be derived from the fact that the independent Croatian state has been in existence for less than 20 years. According to the figures of 2010 of CEMR Croatian municipalities formed settlement twinning contacts in the highest number (67) with their Hungarian partners. They developed 59 relationships with Italian municipalities while they established 40 such co-operations with Slovenian ones. ${ }^{23}$

\section{The intensity of twin settlement relationships in Hungary}

According to point of Art 32 (1) k) of the Fundamental Law of Hungary a Hungarian local government „can freely form associations with another local government, can create advocacy alliances, can cooperate with local governments of other countries in its authority and jurisdiction as well as be a member of international municipal organizations". ${ }^{24}$

The connections, created before the regime change, were established mainly for political reasons by governmental order. The town twinning movement served a twofold goal: it was meant to realize foreign affairs goals with specific tools and to take over public administration experiences. $^{25}$

The initially formal co-operations gradually widened so on top of the cultural groups and sport clubs, the socialist companies also became partners in the cooperation. Besides the formal protocol visits, exchange of professional experience, brigade meetings and networking between families started. The regime change provided an opportunity to form new

\footnotetext{
22 Enter our universe of twinning! http://www.twinning.org/en/page/enter-our-universe-oftwinning\#.U4tTI_1_swQ,

${ }^{23}$ Európai Önkormányzatok és Régiók Tanácsa [Council of European Municipalities and Regions] (2010). http://www.twinning.org/uploads/assets/news/Number\%20of\%20twinnings\%20in\%20Europe\%20in\%202010.pd f

${ }^{24}$ Magyarország Alaptörvénye (2011). [Fundamental Law of Hungary] http://net.jogtar.hu/jr/gen/hjegy_doc.cgi?docid=A1100425.ATV

${ }_{25}$ Farkas, O. (1987). A tanácsok nemzetközi kapcsolatai [International connections of councils] Állam és közigazgatás, p. 47.
} 
relationships. $^{26}$

With the exception of the Pécs-Osijek (1973) and the even older Mohács-Beli Manastir (1970) twinning agreements, the Croatian-Hungarian settlement twinning relationships were formed after the regime change. The process received a big impetus by the fact that during the Yugoslav Wars between 1991-1995 Hungarian cities helped Croatian refugees with hospital treatments, providing education for their children or providing temporary accommodation for families.

In the next phase at the beginning of 2000s tourism took centre stage. During this period the municipalities of Somogy County were looking for partners on the Croatian coast.

As the effect of the Hungarian-Croatian IPA Cross-border Cooperation Programme 20072013 the settlement twinning relationships received a boost again and new ones were formed. During this time period the two main directions of the co-operation were writing and managing joint tenders and preparing for the Croatian EU-accession. ${ }^{27}$

The Social Research Institute carried out an extensive twin settlement research in Hungary in 2002 for the last time. The leaders of the research, Johanna Giczi and Endre Sik studied where, how and for what reasons certain settlements form short-term or long-term relationships, in what form this relationship is realised and what characterises the co-operation between the towns and villages in the relationship. " $33 \%$ of the Hungarian settlements have town twinning connections. Out of this, $62 \%$ have a connection with one town, $18 \%$ have with two, $10 \%$ have with three while the remaining $10 \%$ have connections with four or more foreign towns. $27 \%$ of the settlements are in close communication with Romania, $21 \%$ with Germany and $13 \%$ with Slovakia. Our ties are also significant with Austria, Finland, France, Croatia and Italy.",28

\section{The intensity of twin settlement relationships in Croatia}

The idea of generating twin settlement relationships is not a recent one in Croatia, either. To become a full member of the European Union, Croatia could not have imagined a better way

\footnotetext{
${ }^{26}$ Gergó, Zs. (2006). A transznacionális és mikroregionális hálózatok szerepe és működése [The role and function of transnational and micro-regional networks] In: Kaiser Tamás: Hidak vagy sorompók? A határon átívelő együttműködések szerepe az integrációs folyamatban. Új Mandátum Könyvkiadó, Budapest, p. 179.

${ }^{27}$ A magyar-horvát testvérvárosi megállapodások története, a testvérvárosi kapcsolatfelvétel technikai szakaszai és protokollja [The history of Hungarian-Croatian town twinning agreements; the technical stages and the protocol of attempts to establish town twinning] (2012). http://www.hmep.eu/hu/testverek-vagyunk/72-amagyar-horvat-testvervarosi-megallapodasok-toertenete-a-testvervarosi-kapcsolatfelvetel-technikai-szakaszaies-protokollja-.html

${ }^{28}$ Giczi, J., Sik E. (2004). A települések kapcsolati tőkéjének egy típusa - A testvértelepülések [One type of social capital of town twinning - Twin towns] Szociológiai Szemle, p. 36.
} 
than to prove that it respects other nations' culture and show its own traditions. The formation and maintenance of twin settlement networks significantly contributed to this effort. ${ }^{29}$

Based on Art. 14-17 of the Act on Local and Regional Municipalities in Croatia the municipalities and counties can establish a co-operative agreement with other local and regional municipalities of other countries. The representative body of the municipality can make a decision to establish an international cooperation and the Ministry of Public Administration of the Croatian Republic verifies the legality of it; after that the government can supervise it. ${ }^{30}$

The average length of the official twin settlement relationships is only about 12 years, which can be attributed to the short history of Croatian municipalities. For Croatia, the main goal of establishing twin settlement relationships is the protection of the culture of the Croatian minority groups living in other countries and the more efficient maintenance of ties with the scattered population. The Croatian settlements have four important criteria in mind when they choose a twin settlement: geographical closeness, the presence of national minority, humanitarian activities and the state of affairs of tourism. ${ }^{31}$

Out of the 20 counties of Croatia, Istria has the most twin settlement relationships -38 - in the European Union. It is followed by Seaside-Mountain Area with 35, then Split-Dalmatia with 33 partners. It is interesting that these three counties are the most developed in terms of tourism. $^{32}$

\section{The characteristics and possibilities of the Croatian-Hungarian cross-border co- operation}

The first studies concerning the problems of the Croatian-Hungarian cross-border cooperation were published in the middle of the 1990s. The University of Pécs as an active participant of the co-operation closely examined the different features of the Hungarian border areas and settlements with regards to the possibility of establishing interregional cooperations. We can talk about the continuous increase of Croatian-Hungarian scientific

\footnotetext{
${ }^{29}$ Ercegović, M., Ivanović M. (2009). Bratimljenje gradova i sve što o njemu morate znati [Town twinning and everything you need to know about it] Zagreb, Publisher: Udruga općina u Republici Hrvatskoj, p. 5.

${ }^{30}$ Bakota, B., Fábián, A., Ljubanović, B. (2013). „Határtalan” önkormányzati együttműködés Horvátországban és Magyarországon ["Borderless" co-operation of local governments in Croatia and Hungary] In: Drinóczi Tímea - Novák Barnabás (szerk.) Jog - Régiók - Fejlesztés, Pécsi Tudományegyetem Állam- és Jogtudományi Kara, Pécs, pp. 157-167.

${ }^{31}$ Damjan, M. (2009). Bratimljenje gradova-primjeri dobre prakse iz Hrvarske [Town twinning - examples of good practice from Croatia] Zagreb, Kiadó: Udruga općina u Republici Hrvatskoj, p. 5.

${ }^{32}$ Damjan ib. p. 3.
} 
connections from 1998; however, it is a crucial question how to maintain co-operations and how to manage the "ties" in the social sphere. ${ }^{33}$

Figure 1 Levels of interactions of the cross-border regions
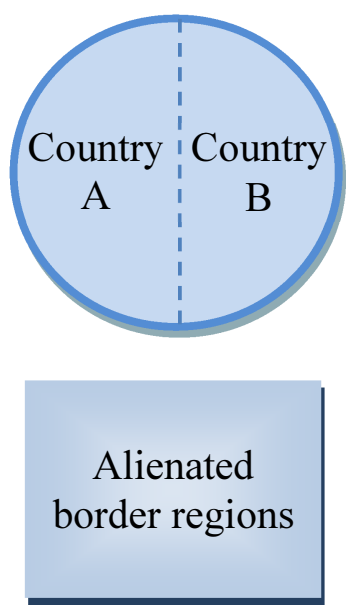

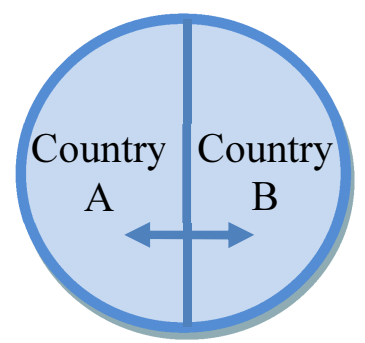

Border regions existing side by side

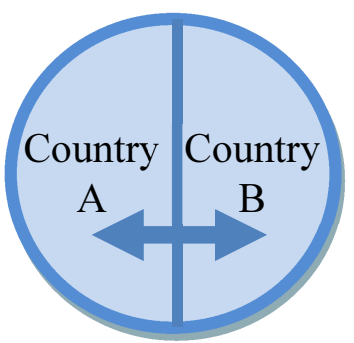

Mutually cooperating border regions

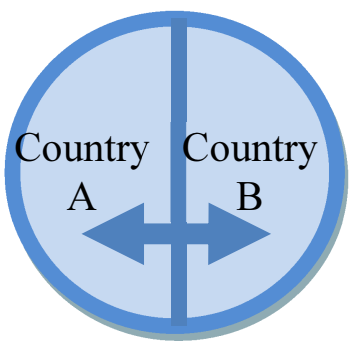

Integrated border regions

Source: Hardi et al., 2009, p. 30.

The development of the Croatian-Hungarian border region could be described by existing side by side in 1990s reached the level of mutual co-operation. The co-operation between the two countries is characterized by stability and the social complements facilitate establishing interactions. But the interactivity which is necessary for the highest level has not been achieved yet. $^{34}$

The number of those co-operations that move bottom up from their own resources is insignificant. Only those co-operations are capable of functioning that are externally supported and "controlled" by the state and the local government. ${ }^{35}$

Following the Croatian-Hungarian Compromise of 1868 the Hungarian-Croatian border only had public administrative function although it continued to be a dividing line as regards ethnicity and identity. The river Drava flowing between the two countries at a length of 144 $\mathrm{km}$ plays a separating role due to its limited navigability; moreover, it is joined by the

\footnotetext{
${ }^{33}$ Bali, L. (2012). A horvát-magyar határon átnyúló kapcsolatok jelene és jövője [The present and future of Croatian-Hungarian cross-border relations] Underground Kiadó és Terjesztő Kft. Budapest-Szepetnek, pp. 122123.

${ }^{34}$ Hardi, T., Hajdú, Z., Mezei, I. (2009). A határ menti városaink helyzete a 21. század elején [The condition of the towns in the border region in the early 21 st century] In Hardi, T., Hajdú, Z., Mezei, I. (2009). Határok és városok a Kárpát medencében. MTA Regionális Kutatások Központja, Györ-Pécs, p. 30.

${ }^{35}$ Bali, L., Kurilla, A. (2011). Pécs és Eszék testvérvárosi kapcsolatai és azok néhány interregionális aspektusa. [Twin town connections of Pécs and Osijek and some of their inter-regional aspects] Comitatus: önkormányzati szemle. p. 65.
} 
disadvantageous traffic and spatial structure conditions as well as the underdevelopment of human resource. ${ }^{36}$

Cross-border territories belong to the rural area on both sides of the border; that is, they are characterised by a loose network of settlements without a centre and a society that is only capable of innovation restrainedly. ${ }^{37}$

The enterprises can improve the quality of life and shape the identity of the HungarianCroatian cross-border region by creating new jobs. On the other hand, it is necessary to establish a coalition of forces and collaboration of inhabitants in the region. ${ }^{38}$

The lack of bridges over the river Drava - which is a geographical border - makes the relationship between South-Transdanubia and the Croatian periphery more difficult since travelling is only possible with great detours. Along some of the border sections the relationship between citizens is quite active; however, the institutionalized partnerships are still at a low level. ${ }^{39}$

So far the results of the research in the Croatian-Hungarian border region have shown that decision makers - on both sides of the border - see the best co-operation possibilities in tourism, in developing the infrastructure of public roads and in the education and culture. ${ }^{40}$

\section{Statistical data of the studied settlements}

We have sent the questionnaire to Hungarian municipalities with five different types of legal status. Almost half of the respondent settlements were villages. 20 towns and 4 towns of county rank filled out the questionnaire. Additionally, two large villages and one county council answered. On the Croatian side six towns and four villages filled out the research questionnaire. The geographical position of the respondent settlements can be seen in the figure below (Fig. 3).

\footnotetext{
${ }^{36}$ Bali ib, p. 149.

${ }^{37}$ Bali, L. (2006). A horvát-magyar határ sajátosságai, a határon átnyúló kapcsolatok kérdései [The characteristic features of the Croatian-Hungarian border, the issues of the cross-border connections] In: Pap N. (szerk.) A Balatontól az Adriáig, Pécs, Lomart Kiadó, p. 149.

${ }^{38}$ Péter E. - Weisz M. - Kovács E. (2009). Analysis of the Retail Trade and Catering Sector in the Largest Rural Resort Area of Hungary (Lake Balaton), Acta Agriculturae Serbica, Vol. XIV, 27 (2009) p. 78.

${ }^{39}$ Bacsi, Zs., Kovács, E. (2007). Határrégiók fejlődésének sajátosságai [The characteristic features of the development of border regions] Keszthely-Hévíz Kistérségi Többcélú Társulás - Nyugat-Balatoni Társadalomtudományi Kutatómühely, Keszthely, p. 122.

${ }^{40}$ Svržnjak, K., Kantar, S., Jerčinović, S., Gajdić, D. (2014). Az ökoturizmus fejlesztési lehetőségei KaproncaKőrös megyében [The development potentials of ecotourism in Koprivničko-križevačka County] p. 6.
} 
Figure 3 Geographical position of the respondent settlements

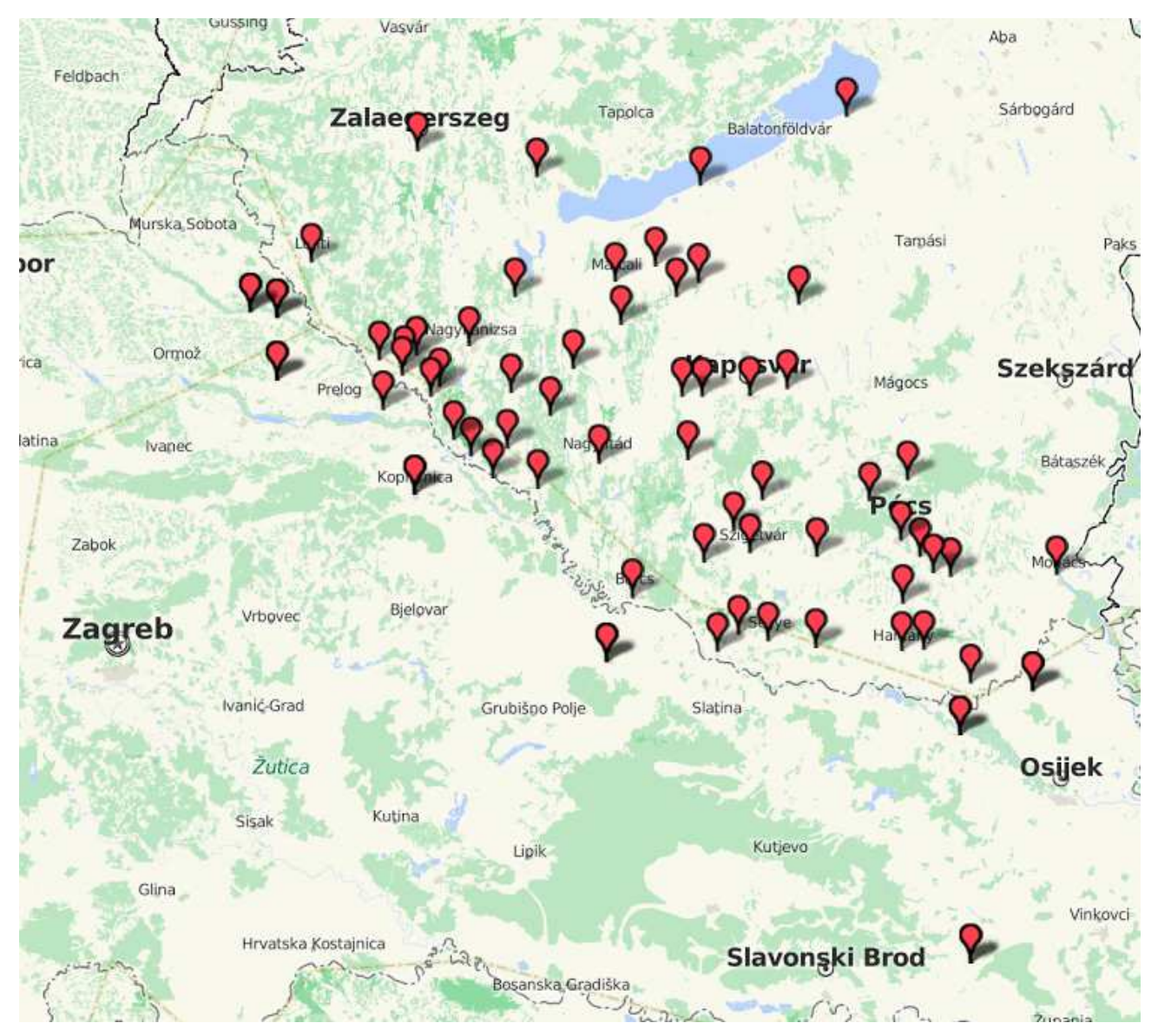

Source: own design of the authors

The majority of the responding Hungarian municipalities can be found in Somogy County, whereas the municipalities in Baranya County answered in almost the same number, which constituted $38.6 \%$ of the sample. Compared to this, Zala County (11 respondents) represents less importance $(21,1 \%)$ in the sample.

From the Croatian communities four are situated in Međimurska county, three in Osječkobaranjska county, two in Koprivničko-križevačka county and one in Virovitičko-podravska county.

The average population of the responding Hungarian municipalities was 10.523. The lowest number was 110 people while the highest was 156.000 . The population living in the territory of Somogy County Council is 318.000 .

The average population of the responding Croatian municipalities was 14.066. The lowest number was 2.336 whereas the highest was 37.200 .

Out of the 52 Hungarian respondents 28 have an operating Croatian Minority Government. Out of the 10 Croatian municipalities that responded to our survey only one, Beli Manastir has a Hungarian Minority Government. 


\section{Advantages of twin settlement co-operation}

Our next question was concerned with the advantages of the co-operation. The majority (in 44 cases) named the possibility for local citizens to meet each other, the sharing of experiences between leaders of local governments and the popularization of the settlement as a tourist destination (in 34-34 cases). These were followed by the opportunity of getting financial resources from tenders (in 27 cases), while 25 municipalities considered the promotion of shared interest to be an advantage of the co-operation. The educational co-operation (in 18 cases), the popularization of the settlement as a foreign investment destination (in 15 cases) and the disaster management (in 2 cases) goals were mentioned the least often. The latter example is surprising considering the fact that numerous Hungarian and Croatian twin settlements are located right at the border, which means that they should be prepared to manage disaster situations together.

Compared to the Hungarians, the Croatian municipalities see opportunities for cooperation in a lot more fields. 9-9 respondents mentioned the possibility of getting financial resources from tenders, the sharing of experiences between local authority officials, the „popularization" of the settlement abroad as a tourist destination or investment and 8 of them mentioned the enforcing shared interests. Seven of them listed the educational co-operation and five of them the chance for local citizens to meet each other. Similarly to the Hungarian respondents, the disaster management goals were mentioned the least but considering the number of respondents these four references indicate that this subject is more important on the Croatian side.

\section{The target groups of the twin settlement relationships}

We considered it to be important to raise the question of what kind of target groups the municipalities have in this area.

The majority of the target groups of the twin settlement relationships were the elected representatives (in 45 cases). The staff members of the municipality (in 35 cases) and local enterprises (in 34 cases) were listed in almost equal numbers. What we consider to be a negative characteristic is the fact that the participation of local associations and clubs (in 28 cases), cultural institutions (in 25 cases) and local citizens (in 18 cases) is far from adequate bigger emphasis has to be put on how to get them involved.

The Croatian settlements mentioned the elected local representatives, local associations and clubs (in 9-9 cases), cultural institutions (in 8 cases) and local enterprises (in 6 cases) most often. Similarly to Hungary, the local citizens are pushed into the background also in 
Croatia - only 3 municipalities listed them as target groups for twin settlement relationships. Employees of the municipality were listed twice.

\section{Participation of local citizens in twin settlement relationships}

In our opinion one of the most important questions related to twin settlement relationships is how much the participating partners can get the local population involved.

The majority of the municipalities (21) were only able to address less than $20 \%$ of the population. It is notable that in 20 cases $20-39 \%$ of the population, in seven occasions $40-59 \%$ of the population takes part in locally organized events where twin settlements also participate. In four cases this proportion is even bigger and reaches or exceeds $60 \%$.

The less than $20 \%$ participation rate definitely has to be improved and the respondents had the opportunity to elaborate the method of this in the framework of an open question.

The majority of the respondents saw the solution in organizing programmes: they would like to have even more and more diverse cultural and traditional events (in 8 cases) and we have received suggestions for other programmes (sport events, activities for children) that would be interesting for ,a wider range of the population” (in 8 cases).

A number of communities came up with the idea of starting exchange programmes, where the participants would spend the night at the other village and the exchange-holidays or student-exchange programmes could provide an excellent opportunity to get to know each other better (in 4 cases). Another three municipalities also mentioned giving tasks to the local population.

Seven municipalities agreed that the co-operation should be expanded involving „institutions, civic organizations and employees of municipalities” or finding local producers, cultural communities and asking them to participate actively. Three respondents mentioned that bigger financial support is needed to be able to achieve this goal.

In Croatia the local citizens are less involved in the twin settlement events. Eight respondents mentioned that the participation rate does not even reach $20 \%$. Only one put the rate between 20 and $40 \%$ and one between 40 and $60 \%$.

To improve this rate the Croatian respondents provided similar answers as the Hungarians: they suggested organizing educational, cultural, sport and touristic programmes, better informational campaigns and the co-operation between companies.

\section{Frequency of co-operation}

The success of the co-operation is indicated by the frequency of contact between the partners. To the question regarding the frequency of contact 26 municipalities reported that the contacts 
are intensive since they meet on more than two occasions a year. 15 communities co-operate on some issue twice a year, while 7 do so once a year. Some of the respondents mentioned that meeting even once a year is not realized: one of them contacted their Croatian partner once in every three years, whereas another three said that in their cases the communication practically ceased since they contact each other even less frequently than the above mentioned time periods.

Half of the Croatian communities reported that they meet their Hungarian partners more often than twice a year, while three of them said they meet twice a year and two said they meet once a year.

\section{The successfulness of the relationships with the Croatian twin settlement}

The next question deals with the successfulness of the relationships with the Croatian twin settlement. We have asked the respondents to evaluate their co-operation based on different aspects on a five-scale Likert-scale (according to school grades: 1: not satisfied at all, 5: fully satisfied).

Figure 4 The successfulness of the different aspects of the co-operation with the Croatian twin settlement in case of the respondent Hungarian municipalities

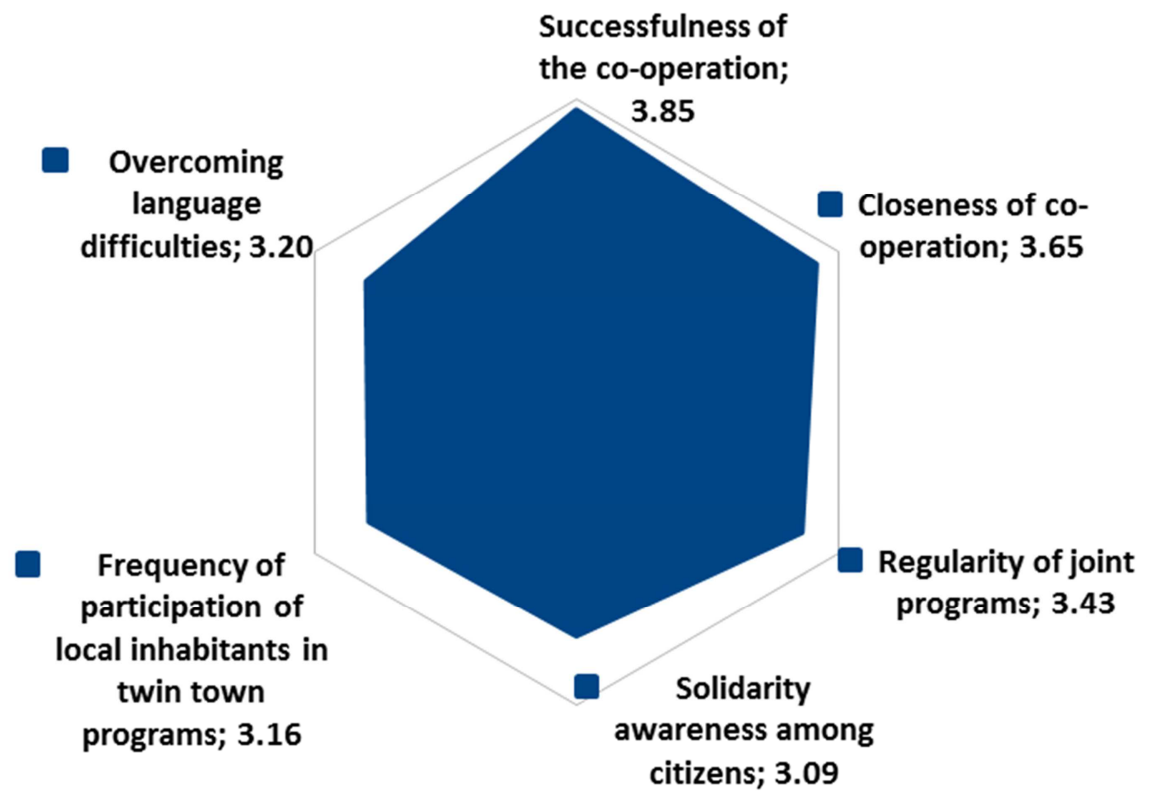

Source: own research

Before the evaluation we started with the assumption that we will consider a given region successful if the satisfaction rate reaches 4.00 on average. 
Results show that the respondent municipalities do not consider the cooperation successful on the whole since the arithmetic mean measured on the five-scale Likert-scale was 3.85. However, we have to emphasize that there were several municipalities that provided a fail (in 3 cases) or pass mark (in 2 cases) to this question but these municipalities did not even meet once in every three years. It is, nevertheless, important to highlight that 21 municipalities gave a good mark, while 10 of them considered the co-operation to be excellent.

Neither were respondents satisfied with the closeness of co-operation (3.65) and the regularity of joint programs (3.42) in all cases. It is also noticeable in the above figure that the weakest points in the relationships are indicated by the overcoming of language difficulties (3.2), involvement of the local population in the programs (3.16) and the solidarity awareness of the citizens (3.09).

\section{The successfulness of the relationships with the Hungarian twin settlement}

Figure 5 The successfulness of the different aspects of the co-operation with the Hungarian twin settlement in case of the respondent Croatian municipalities

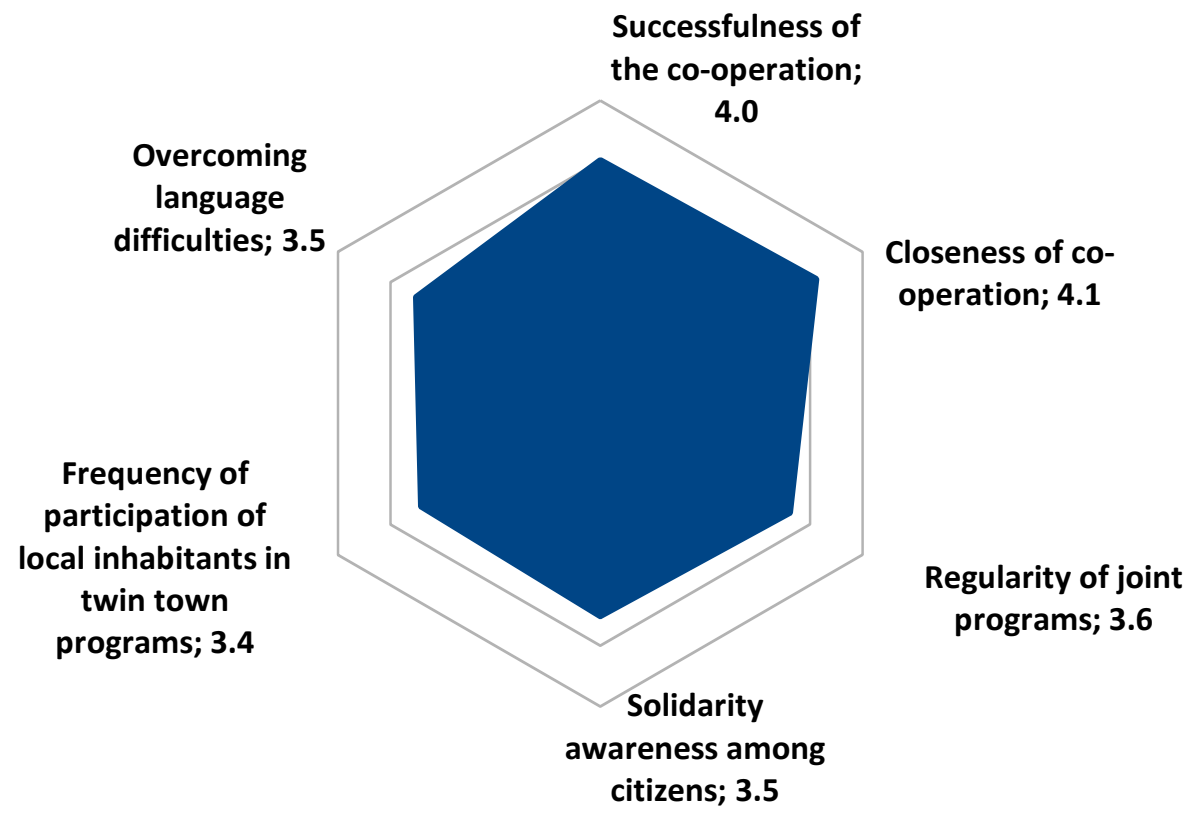

Source: own research

We have also asked the Croatian respondents what they think about the co-operation with their Hungarian twin settlement.

The values seen on the above figure are higher regarding all the factors than in the case of the Hungarian answers so all in all, we can say that the Croatian respondents are more satisfied with the co-operation. 
The Croatian respondents were most satisfied with the closeness $(4,1)$ and with the successfulness $(4,0)$ of co-operation. It is important to stress that only one community regarded the relationship as a failed one, while five considered the joint work to be excellent.

\section{Cross tabulation analysis}

We carried out a crosstab analysis to find out whether the seven factors described in the research model are connected - and if yes to what extent - to the successfulness of the twin settlement relationships. We would have liked to do this analysis with regard to both countries; however, since a sample with at least 30 items from Croatia would have been necessary to do this, we could only do this calculation with the data received from the Hungarian settlements.

During the research we examined the correlation between the variables and the Chi square test provides the answer to this. This statistics measures the statistical significance of the correlation between the two variables. To reach a significant result the value of the index has to be under the chosen $p<0,05$ threshold significance level. However, it is important to note that "one of the main characteristics of the Chi-square statistics is that it is sensitive to sample size since the Chi-square is linearly dependent on the number of items in the sample, which means that in the case of same distribution it can occur that two variables do not show significant results with low item number while with high item number they do". As our sample can be considered to contain a relatively low item number, we will draw conclusions even when there is no significant correlation between the variables based on the test statistics. "In case there is no correlation we can still analyze the cross-table but we have to add to our findings that the result did not prove significant." ${ }^{41}$

Summarizing the obtained results it can be ascertained that the result was only significant in the case of a single factor: there is moderately strong correlation (Cramer V: 0,403, significance level: 0,007) between the frequency of contacts and their successfulness.

The significance level $(0,12)$ is above the chosen threshold; however, it is still worth investigating the correlation between the operation of the Croatian Minority Government and the successfulness of twin settlement relationships. In the area of those five municipalities that gave a fail (1) or pass (2) mark for the co-operation with their Croatian twin settlement there is no Croatian Minority Government in function. Out of those municipalities that gave a

\footnotetext{
${ }^{41}$ Sajtos, L., Mitev, A. (2007). SPSS Kutatási és adatelemzési kézikönyv [SPSS Research and data analysis manual] Budapest, Aliena Kiadó, p. 156.
} 
"good" mark twelve had, while nine did not have minority governments. The difference is even more visible in case of those municipalities that considered the co-operation to be excellent: out of the 16 respondents eleven reported a Croatian Minority Government.

For this reason we presume that - even if not in a statistically significant way - there is a correlation between a functioning Croatian Minority Government and the successfulness of the twin settlement relationship.

The correlation between the participation rate of the population in the twin settlement programs and the successfulness of the twin settlement relationship was the subject of the next study. We cannot talk about a significant correlation in this case either, since the significance level (0.31) exceeds the chosen level here as well. Again, it is worth exploring the percentage values of the above table as they are pointing out some useful correlations.

In those communities, where at least $40 \%$ of the population participates in the twin settlement programs, co-operation is considered to be at least good; out of the eleven respondents none of them gave even a mediocre evaluation. Four of the five respondents who gave a fail or pass grade for the successfulness of the relationship had less than $20 \%$ of the population participating in the events so the involvement of the citizens is quite insignificant. For this reason we believe that - even if not in a statistically significant way - it can be stated that there is a correlation between the above mentioned two factors.

In case of appointing a person responsible for twin settlements in charge at the local authority, the existence of joint tenders and the realization of economic co-operations, our hypothesis - that these have an effect on the success of twin settlement relationships - was not verified.

Taking these results into account the successfulness of twin settlement relationship is shown in the following diagram (Fig. 6). 
Figure 6 Research model showing the results

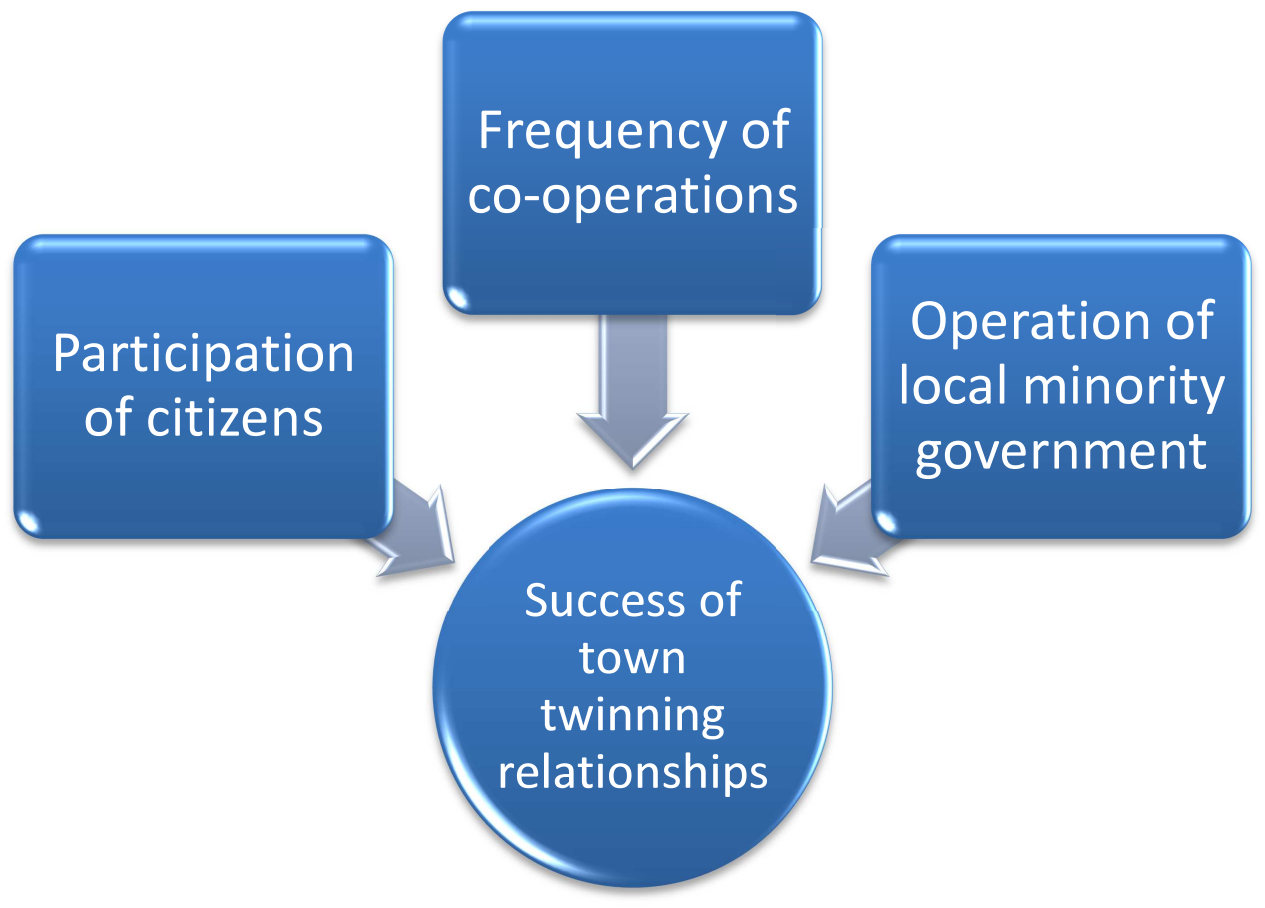

Source: own research

\section{CONCLUSION}

In our research we studied the available Hungarian and Croatian scientific literature with regards to the history of twin settlement relationships and their intensity in the European Union.

In research comprising a quantitative method we have studied the factors generating settlement twinning relationships, the nature of these relationships, their current content and their institutional background in the Hungarian-Croatian cross-border region. We have also explored what benefits the studied local authorities think they can gain from the cooperation, which target groups are involved and to what extent it was successful to involve the inhabitants. The questionnaire survey research included cooperation between settlements in counties Zala, Somogy and Baranya on the Hungarian side as well as in counties Međimurska, Koprivničko-križevačka, Virovitičko-podravska and Osječko-baranjska on the Croatian side.

According to the respondents the twin settlement relationships would primarily mean the opportunity for the local citizens to meet, for the local authorities to share their experiences and promoting the community as a tourist destination. 
We considered the involvement of the population as one of the most important issue since in 41 settlements less than $40 \%$ of the inhabitants participate in the programs; this rate definitely needs to be improved.

During our empirical research we have pointed out that between the Hungarian and Croatian communities the relationship is generally intensive but naturally there are negative examples as well. The studied Hungarian communities generally assessed their twin settlement relationships as mediocre - the solidarity awareness of the population got the lowest value, while the successfulness of the co-operations received the highest. It is important to emphasize that the Croatian respondents were more satisfied in every aspect than their Hungarian partners.

During the testing of our initial research model we have detected significant and moderately strong correlation between the frequency and the successfulness of the twin settlement relationships. We have also ascertained that the existence of Croatian Minority Governments and the active participation of the population in the jointly organized programs can also have an effect on the positive assessment of the twin relationships.

\section{Acknowledgement}

The research was carried out in the framework of the project „National Excellence Program - Campus Hungary development of the personal support system of international student mobility convergence programme in connection with $\mathrm{R}+\mathrm{D}$ projects and study programs" Social Renewal Operational Programme (TÁMOP-4.2.4B/2-11/1-2012-0001).

\section{REFERENCES}

Bacsi, Zs., Kovács, E. (2007). Határrégiók fejlődésének sajátosságai, Keszthely-Hévíz Kistérségi Többcélú Társulás - Nyugat-Balatoni Társadalomtudományi Kutatómühely, Keszthely, p. 122.

Bakota, B., Fábián, A., Ljubanović, B. (2013). „Határtalan” önkormányzati együttműködés Horvátországban és Magyarországon: Drinóczi Tímea - Novák Barnabás (szerk.) Jog Régiók - Fejlesztés, Pécsi Tudományegyetem Állam- és Jogtudományi Kara, Pécs, pp. 157-167.

Bali I., Ürmössy I. (2004). Testvértelepülési kapcsolatok a gyakorlatban [Town twinning connections in practice] Krónika-4 Bt., Szolnok. p. 5.

Bali, L. (2006). A horvát-magyar határ sajátosságai, a határon átnyúló kapcsolatok kérdései [The characteristic features of the Croatian-Hungarian border, the issues of the crossborder connections] In: Pap N. (szerk.) A Balatontól az Adriáig, Pécs, Lomart Kiadó, p. 149.

Bali L. (2009). A horvát-magyar határon átnyúló kapcsolatok politikai földrajzi sajátosságai az egyes területi szinteken [Political and geographical specific features of the connections reaching over Hungarian-Croatian border region on the certain territorial levels] Pécsi Tudományegyetem Földtudományok Doktori Iskola, p. 18-65. 
Bali, L., Kurilla, A. (2011). Pécs és Eszék testvérvárosi kapcsolatai és azok néhány interregionális aspektusa. [Twin town connections of Pécs and Osijek and some of their inter-regional aspects] Comitatus: önkormányzati szemle. p. 65.

Bali, L. (2012). A horvát-magyar határon átnyúló kapcsolatok jelene és jövője [The present and future of Croatian-Hungarian cross-border relations] Underground Kiadó és Terjesztő Kft. Budapest-Szepetnek, pp. 122-123.

Damjan, M. (2009). Bratimljenje gradova-primjeri dobre prakse iz Hrvarske [Town twinning - examples of good practice from Croatia] Zagreb, Kiadó: Udruga općina u Republici Hrvatskoj

Ercegović, M., Ivanović M. (2009). Bratimljenje gradova i sve što o njemu morate znati [Town twinning and everything you need to know about it] Zagreb, Publisher: Udruga općina u Republici Hrvatskoj

Farkas, O. (1987). A tanácsok nemzetközi kapcsolatai [International connections of councils] Állam és közigazgatás, p. 47.

Gergó, Zs. (2006). A transznacionális és mikroregionális hálózatok szerepe és müködése [The role and function of transnational and micro-regional networks] In: Kaiser Tamás: Hidak vagy sorompók? A határon átívelő együttmüködések szerepe az integrációs folyamatban. Új Mandátum Könyvkiadó, Budapest. p. 179.

Giczi, J., Sik E. (2004). A települések kapcsolati tőkéjének egy típusa - A testvértelepülések [One type of social capital of town twinning - Twin towns] Szociológiai Szemle, p. 36.

Hardi, T., Hajdú, Z., Mezei, I. (2009). A határ menti városaink helyzete a 21. század elején [The condition of the towns in the border region in the early 21st century] In Hardi, T., Hajdú, Z., Mezei, I. (2009). Határok és városok a Kárpát medencében. MTA Regionális Kutatások Központja, Győr-Pécs

Péter E. - Weisz M. - Kovács E. (2009): Analysis of the Retail Trade and Catering Sector inthe Largest Rural Resort Area of Hungary (Lake Balaton), Acta Agriculturae Serbica, Vol. XIV, 27, pp. 63-78.

Sajtos, L., Mitev, A. (2007). SPSS Kutatási és adatelemzési kézikönyv [SPSS Research and data analysis manual] Budapest, Aliena Kiadó, p. 156.

Svržnjak, K., Kantar, S., Jerčinović, S., Gajdić, D. (2014). Az ökoturizmus fejlesztési lehetőségei Kapronca-Körös megyében [The development potentials of ecotourism in Koprivničko-križevačka County]

A magyar-horvát testvérvárosi megállapodások története, a testvérvárosi kapcsolatfelvétel technikai szakaszai és protokollja [The history of Hungarian-Croatian town twinning agreements; the technical stages and the protocol of attempts to establish town twinning] (2012). http://www.hmep.eu/hu/testverek-vagyunk/72-a-magyar-horvattestvervarosi-megallapodasok-toertenete-a-testvervarosi-kapcsolatfelvetel-technikaiszakaszai-es-protokollja-.html

Április 28. A Testvérvárosok Világnapja [28 April - World Twin Town Day] (2013). http://www.mtva.hu/hu/sajto-es-fotoarchivum/4719-aprilis-28-a-testvervarosokvilagnapja

Enter our universe of twinning! http://www.twinning.org/en/page/enter-our-universe-oftwinning\#.U4tTI_1_swQ,

Európai Önkormányzatok és Régiók Tanácsa [Council of European Municipalities and Regions]

http://www.twinning.org/uploads/assets/news/Number\%20of\%20twinnings\%20in\%20E urope\%20in\%202010.pdf

Introducing CEMR, http://www.ccre.org/en/article/introducing_cemr

Magyarország Alaptörvénye (2011) [Fundamental Law of Hungary]. http://net.jogtar.hu/jr/gen/hjegy_doc.cgi?docid=A1100425.ATV 
Mit takar a testvérkapcsolat kifejezés? - Rövid áttekintés [What does the term 'twin town connection' refer to ? - $\quad$ Summary review] http://www.twinning.org/hu/page/r\%C3\%B6vid$\% \mathrm{C} 3 \%$ A 1 ttekint $\% \mathrm{C} 3 \%$ A9s\#.U9Forfl_swQ

The constitution of the world organisation of United Cities and Local Governments. http://www.cities-

localgovernments.org/uclg/upload/template/templatedocs/Constitution.pdf 